\title{
Effect of Heat Treatment on the Gas Permeability, Sound Absorption Coefficient, and Sound Transmission Loss of Paulownia tomentosa Wood ${ }^{1}$ 踝
}

\author{
Chun-Won $\mathrm{KANG}^{2} \cdot$ Eun-Suk JANG $\mathbb{D}^{2, \dagger} \cdot$ Sang-Sik JANG ${ }^{3}$ • \\ Jae-Ik $\mathrm{Cho}^{4} \cdot$ Nam-Hun $\mathrm{KIM}^{4}$
}

\begin{abstract}
In this study, the gas permeability, sound absorption coefficient, and sound transmission loss of the Paulownia tomentosa wood were estimated using capillary flow porometry, transfer function method, and transfer matrix method, respectively. The longitudinal specific permeability constant of the Paulownia tomentosa wood with a thickness of $20 \mathrm{~mm}$ was 0.254 for the control sample and $0.279,0.314$, and 0.452 after being subjected to heat treatments at $100{ }^{\circ} \mathrm{C}, 160{ }^{\circ} \mathrm{C}$, and $200{ }^{\circ} \mathrm{C}$, respectively. The gas permeability was observed to be slightly increased by the heat treatment. The mean sound absorption coefficients of 20-mm thick Paulownia tomentosa log cross-section for the control sample and after being subjected to heat treatments at $100{ }^{\circ} \mathrm{C}, 160{ }^{\circ} \mathrm{C}$, and $200{ }^{\circ} \mathrm{C}$ were $0.101,0.109,0.096$ and 0.106 , respectively. Further, the noise reduction coefficients of 20-mm thick Paulownia tomentosa log cross-section of the control sample and after being subjected to heat treatment at temperatures of $100{ }^{\circ} \mathrm{C}, 160{ }^{\circ} \mathrm{C}$, and $200{ }^{\circ} \mathrm{C}$ were $0.060,0.067,0.062$ and 0.071 , respectively. The mean of sound transmission loss of the 20-mm thick Paulownia tomentosa log cross-section was approximately $36.93 \mathrm{~dB}$. Furthermore, the gas permeability and sound absorption coefficient of the heat-treated Paulownia tomentosa discs slightly increased depending on the heat treatment temperature; however, the rate of increase was insignificant.
\end{abstract}

Keywords: Paulownia tomentosa wood, sound absorption coefficient, sound transmission loss, transfer function method, transfer matrix method

\section{INTRODUCTION}

The growing interest for improving the quality of life in recent years, the environmental noise issues have worsened, and there is a considerable increase in the demand for noise control in residential environments. Accordingly, many studies have investigated building materials that offer excellent sound

1 Date Received May 30, 2019, Date Accepted August 23, 2019

2 Department of Housing Environmental Design, and Research Institute of Human Ecology, College of Human Ecology, Chonbuk National University, Jeonju 54896, Republic of Korea

${ }^{3}$ Department of Forest Products, College of Agriculture \& Life Sciences, Chungnam National University, Daejeon 34134, Republic of Korea

${ }^{4}$ Department of Forest Biomaterials Engineering, College of Forest and Environmental Sciences, Kangwon National University, Chuncheon 24341, Republic of Korea

† Corresponding author: Eun-Suk JANG (e-mail: esjang@jbnu.ac.kr, ORCID: 0000-0001-5995-8617) 
Effect of Heat Treatment on the Gas Permeability, Sound Absorption Coefficient, and Sound Transmission Loss of Paulownia tomentosa Wood

absorption coefficients and the measurement of the sound absorption coefficient.

Sound absorption is a process of absorbing or reducing sound energy using the friction in the pores of porous materials, the vibration of plates or membranes that form layers of air between them and the steel walls, and absorption tools based on resonators (Jang et al., 2018; Kang et al., 2010; Kang et al., 2018a; Kang et al., 2018b) Porous sound absorption offers the sound absorption effect using fiberglass or porous synthetic resin, and fabric and fiberglass are the main examples of porous sound absorption materials. Because of biological characteristics, wood is naturally porous because it contains many pores through which water and nutrients pass; however, its use as a sound absorption material is negligible. Even though wood contains several pores, the direction of these pores is toward the direction of contraction; quartered or block wood are used as the building materials, and wood pores are not exposed to the plane of sound incidence. If the longitudinal wood is used as the plane of sound incidence, wood pores may contribute to sound absorption; even in this case, the tracheid of softwood trees does not have pores at the end of cells, and the pits function as passages so that the penetrating pores effective in sound absorption are narrow. In case of hardwood trees, vessel and perforation plate, through pores effective to sound absorption, and thus, the cross-section of hardwood trees may offer a high sound absorption coefficient. However, there is a large deviation among the species of trees in terms of the size of the diameter of the vessel, the form of the perforation plate between vessel, and the rate of the vessel. Kang et al. (2011) reported that the cross- section of yellow poplar exhibits large-diameter and high-porosity vascular tissues, offering excellent sound absorption performance that there are different sound absorption coefficients in radial direction between heartwood and sapwood (Kang et al., 2011).

Aiming to offer key basic data in the expansion of the usage of the Paulownia tomentosa wood, a fastgrowing tree species in Korea that offers high added value has been investigated. Further, to determine the effect of heat treatment on the gas permeability, crosssectional sound absorption coefficient, and sound transmission loss of the Paulownia tomentosa wood, this study measured the longitudinal gas permeability of the Paulownia tomentosa wood discs after being subjected to heat treatments at $100{ }^{\circ} \mathrm{C}, 160{ }^{\circ} \mathrm{C}$, and $200{ }^{\circ} \mathrm{C}$. The same specimens were used to measure the sound absorption coefficient in longitudinal direction using the transfer function method and the sound transmission loss using the transfer matrix method. The results were subsequently compared with the gas permeability, sound absorption coefficient, and sound transmission loss of the non-treated discs. Thus, the study aimed to evaluate the longitudinal sound absorption performance and sound transmission loss as well as the effect of the heat treatment on the characteristics of the Paulownia tomentosa wood to determine its potential usage as an indoor building material.

\section{MATERIALS and METHODS}

\subsection{Production of specimens and heat treatment}

For this study, 11- to 15-year-old Paulownia woods (Royal paulownia, Paulownia tomentosa (Thunb.) Steud.) that were approximately $30 \mathrm{~cm}$ in diameter at breast height were collected from the research forest at Kangwon National University. The dried specimens were heat-treated at $100{ }^{\circ} \mathrm{C}, 160{ }^{\circ} \mathrm{C}$, and $200{ }^{\circ} \mathrm{C}$ for two hours when the rate of temperature increase was $2{ }^{\circ} \mathrm{C} / \mathrm{min}$.

\subsection{Measurement of the gas permeability}

Gas permeability is the degree by which a gas fluid passes through a porous material, generally expressed 


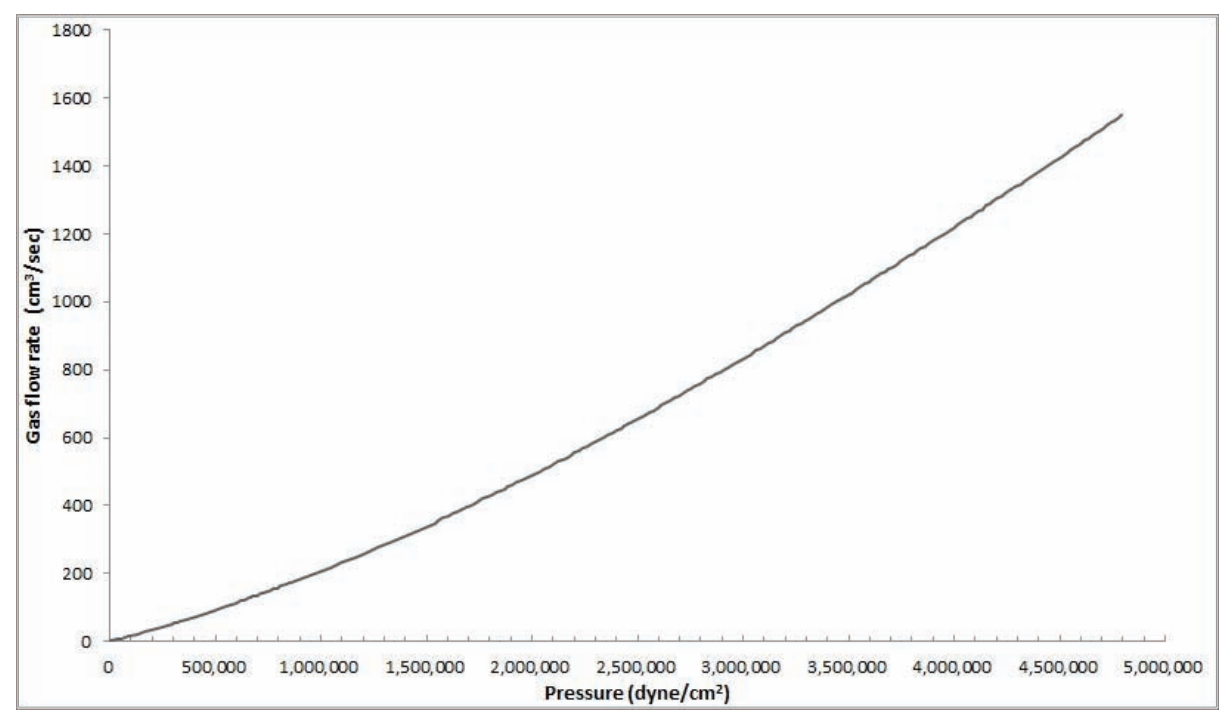

Fig. 1. Gas permeability graph using a capillary flow porometer.

as Darcy's law. 1 darcy is $1 \mathrm{~cm}^{3} / \mathrm{s}$ of gas fluid in the viscosity of $1 \mathrm{cp}(1 \mathrm{mPa} \cdot \mathrm{s})$ from $1 \mathrm{~cm}$ under the pressure of 1 atm.

The test initially measured the change of the flow rate by increasing the pressure using a capillary flow porometer (Model: CFP-1200AEL, Porous material Inc., Ithaca U.S.A) in real time, as shown in Fig. 1, and calculated the specific permeability $(K)$ using Eq. (1) and Eq. (2) (Kang and Lu, 2005).

$$
\begin{gathered}
k=\frac{Q / A}{\Delta P / L} \\
K=1.013 \times 10^{8} \mathrm{k \eta}
\end{gathered}
$$

Here,

$K=$ specific permeability (darcy)

$k=$ permeability $\left(\mathrm{cm}^{4} /\right.$ dyne $\left.\mathrm{s}\right)$

$\eta=$ viscosity of air $\left(1.81 \times 10^{-4}\right.$ dyne $\left.\mathrm{s} / \mathrm{cm}^{2}\right)$

$Q=$ gas flow rate $\left(\mathrm{cm}^{3} / \mathrm{s}\right)$

$A=$ cross-sectional area of the specimen $\left(\mathrm{cm}^{2}\right)$

$\Delta P=$ pressure difference $\left(\right.$ dyne $\left./ \mathrm{cm}^{2}\right)$

$L=$ length of the specimen $(\mathrm{cm})$

\subsection{Measurement of the sound absorption coefficient by the transfer function method}

The sound absorption coefficient in $50-6400 \mathrm{~Hz}$ was measured with the transfer function method using B\&K’s impedance tube, pulse analyzer, and spectrum analyzer according to ISO 10534-2. (Kang et al., 2012) A 29-mm diameter impedance pipe was used to measure the change in the sound absorption coefficient based on the change in frequency from 50 to $6400 \mathrm{~Hz}$.

The external conditions at the time of the measurement, i.e., the temperature, relative humidity, and air pressure, were $18.7{ }^{\circ} \mathrm{C}, 37 \%$, and $1027.50 \mathrm{hPa}$, respectively; further, the speed of sound, air density, and acoustic impedance were $342.48 \mathrm{~m} / \mathrm{s}, 1.224 \mathrm{~kg} / \mathrm{m}^{3}$, $419.3 \mathrm{~Pa} /(\mathrm{m} / \mathrm{s})$, respectively.

\subsection{Measurement of the sound transmission loss by the transfer matrix method}

The sound transmission loss in 50-6400 Hz was measured based on the transfer matrix method using 
Effect of Heat Treatment on the Gas Permeability, Sound Absorption Coefficient, and Sound Transmission Loss of Paulownia tomentosa Wood

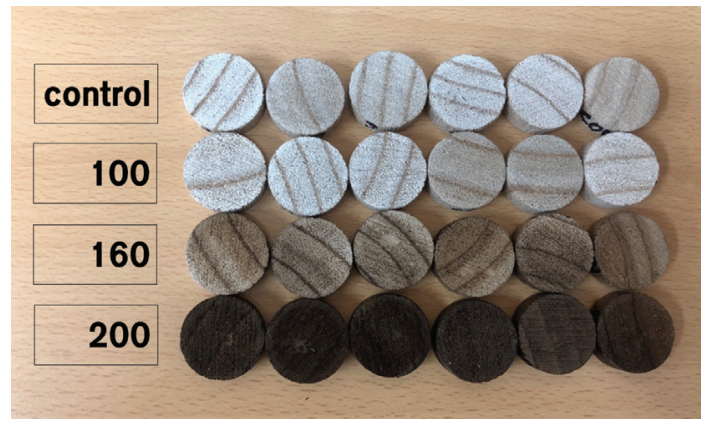

Fig. 2. Sample preparation for measuring the sound absorption ratio and sound transmission loss.

B\&K’s impedance tube, pulse analyzer, and spectrum analyzer according to ASTM E2611-09. A 29-mm diameter impedance tube was used to measure the sound transmission loss in the frequency from 50 to 6400 $\mathrm{Hz}$ at which the temperature and air pressure (external conditions) were $20^{\circ} \mathrm{C}$ and $1031 \mathrm{hPa}$, respectively.

\subsection{Observation by scanning electron micrography}

To observe the porous structure of the cross-section of wood from the specimens of which the sound absorption coefficient, gas permeability, and sound transmission loss were measured, a sample measuring approximately $10 \mathrm{~mm}(\mathrm{~T}) \times 10 \mathrm{~mm}(\mathrm{R}) \times 10 \mathrm{~mm}(\mathrm{~L})$ was obtained from the wood specimens; it was submerged in water for 48 hours under decompression for softening it, and the cross-section of the sample was cleanly obtained using Microtome (Model: HM400S, MicromGmbH, Germany) and observed using a scanning electron microscope (XL30ESEM, Philips, Netherlands).

\section{RESULTS and DISCUSSION}

\subsection{Gas permeability}

Fig. 3 shows the difference in gas permeability between the heat-treated and non-heat-treated Paulownia

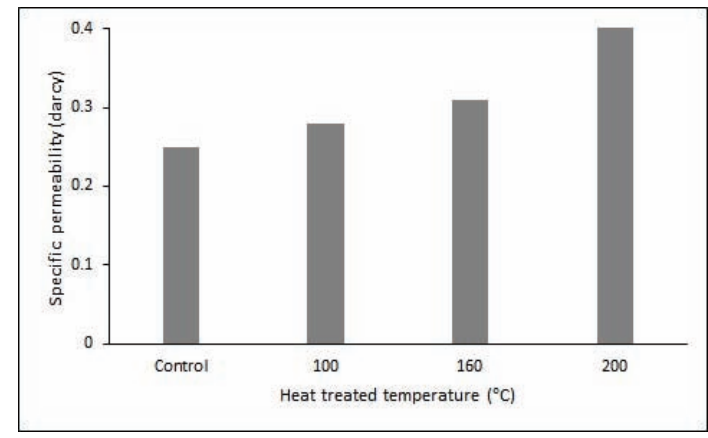

Fig. 3. Gas permeability results.

tomentosa wood specimens. After being subjected to heat treatments at $100{ }^{\circ} \mathrm{C}, 160{ }^{\circ} \mathrm{C}$, and $200{ }^{\circ} \mathrm{C}$, the specific permeabilities of the specimens in case of 20-mm thick wood was $0.254,0.279,0.314$, and 0.452 darcy, respectively; a slight increase in gas permeability was observed after the heat treatment. It is expected that the Paulownia tomentosa wood offers a considerably high gas permeability and sound absorption coefficient because of its low specific gravity, large porosity, and big vessels; however, the overall measurement results were small. This indicates that the big vessels contributing to an increase in gas permeability did not function as expected; as shown in Fig. 6, the cross-sectional surface of the Paulownia tomentosa wood vessels showed many tylosis, which lower penetrating pores that would contribute to the passage of fluid, resulting in low gas permeability. Because of the heat treatment, the gas permeability slightly increased when compared with that of the non-treated specimens. Kang et al. (2018c) reported that when mamala was heat-treated at $200{ }^{\circ} \mathrm{C}$ for three hours, its gas permeability increased eight times and its sound absorption coefficient increased by $40 \%$. When compared with a previously conducted study, this study showed a smaller effect of heat treatment, which may be attributed to the difference in the structure and size of pores, the content of the penetrating pores, the content 
of resin in various species of trees, and the difference in treatment conditions such as the treatment temperature and duration; therefore, further research on these aspects is needed.

\subsection{Sound absorption coefficient using the transfer function method}

Fig. 4 shows the sound absorption coefficient of the heat-treated Paulownia tomentosa wood specimens in 50-6400 Hz using the transfer function method. The mean sound absorption coefficient in $50-6400 \mathrm{~Hz}$ for the non-treated Paulownia tomentosa wood disc with a thickness of $20 \mathrm{~mm}$ was 0.101 , whereas those of the discs subjected to heat treatment at $100{ }^{\circ} \mathrm{C}, 160$ ${ }^{\circ} \mathrm{C}$, and $200{ }^{\circ} \mathrm{C}$ were $0.109,0.096$, and 0.106 , respectively. The NRC were $0.060,0.067,0.062$, and 0.071 , respectively.

If wood is used as boards, it is difficult for wood pores to contribute to sound absorption when sound hits the radial section or tangential section of wood. However, if sound hits the cross-sectional surface of wood, it is easier for wood pores to contribute to sound absorption; thus, the cross-sectional surface of wood with many penetrating pores would offer a higher sound absorption coefficient. The Paulownia tomentosa wood, one of the fast-growing species in Korea, low specific gravity, high porosity, and big vessels so that it can offer high sound absorption coefficient in a cross-section; however, the overall sound absorption coefficient in all the measured frequency ranges was low at approximately $10 \%$. Generally, the sound absorption coefficient of the porous materials increases in the high-frequency range but for the Paulownia tomentosa wood, despite the high porosity, many tylosis were present that caused many pores closing, resulting in the low sound absorption coefficient in case of high frequencies. Furthermore, even after heat treatment, the increase in sound absorption coefficient
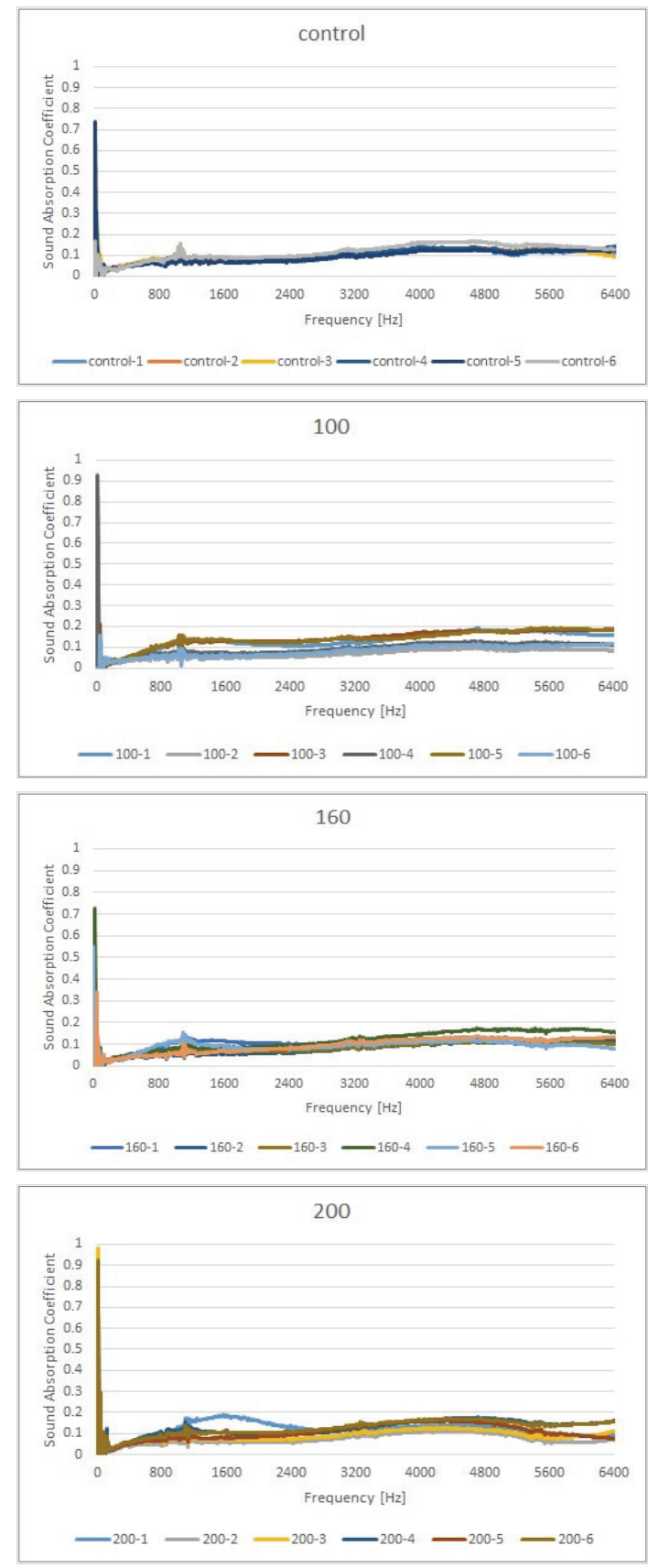

Fig. 4. Relation between the frequency and sound absorption coefficient of the control sample and heattreated Paulownia tomentosa wood (100, 160, and 200 denote the treatment temperature, and graph legend values denote the sample number). 
Effect of Heat Treatment on the Gas Permeability, Sound Absorption Coefficient, and Sound Transmission Loss of Paulownia tomentosa Wood

was negligible, which implies that the contribution of the penetrating pores to porous sound absorption was minimal and that there was no structural change due to the heat treatment. Meanwhile, Kang et al. (2018c) reported the two-fold increase in the sound absorption coefficient of Malas (Homalium foetidum) after heat treatment at $190{ }^{\circ} \mathrm{C}$ for three hours. When compared to that study, this study showed a smaller change due to heat treatment, which may be due to the difference in pores and resin content between tree species as well as the treatment conditions such as temperature and duration; therefore, further research is needed. Meanwhile, the sound absorption property of the porous materials is known to increase in the high-frequency range than in the low-frequency range; however, the Paulownia tomentosa wood showed low sound absorption coefficients in both high- and low-frequency ranges. The low sound absorption coefficient in the high-frequency range can be attributed to the decreased rate of through pores caused by many tylosis in vessels.

\subsection{Sound transmission loss by the transfer matrix method}

Fig. 5 shows the sound transmission loss of the Paulownia tomentosa wood discs in case of a thickness of $20 \mathrm{~mm}$ in 50-6400 $\mathrm{Hz}$.

Sound transmission loss shows the sound-blocking effect of materials; the higher the transmission loss, the higher will be the sound-insulation effect, which depends on the frequency (Kim et al., 2015; Kook et al., 2007; Lee et al., 2011). The graphshows the frequency on $\mathrm{X}$-axis and the sound transmission loss on $\mathrm{Y}$-axis, and the transmission loss is expressed in [dB]. Generally, the higher the frequency and the larger the area density, i.e., the higher the thickness, the higher will be the transmission loss. The sound transmission loss of the non-treated Paulownia tomentosa wood disc

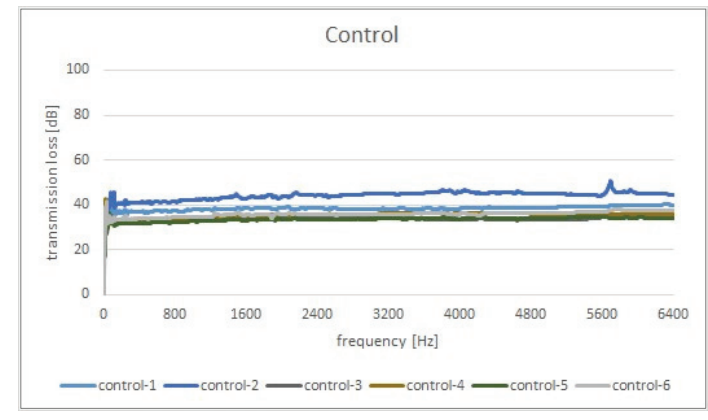

Fig. 5. Relation between frequency and sound transmission loss of the control paulownia tomentosa wood (Graph legend values denote the sample thickness).

having a thickness of $20 \mathrm{~mm}$ was approximately 30-40 and $36.93 \mathrm{~dB}$ on an average in $50-6400 \mathrm{~Hz}$. In case of Paulownia tomentosa wood, the sound transmission loss was high despite its low specific gravity and high porosity.

\subsection{Anatomical features}

Fig. 6 shows the anatomical features of the crosssectional surface of the Paulownia tomentosa wood. It is expected that the sound absorption coefficients of the Paulownia tomentosa wood in longitudinal direction is high because its diffuse porous wood and many big vessels as shown, However, it also contains many tylosis in vessels that would contribute to low sound absorption; therefore, the overall sound absorption coefficient is observed to be low. Such anatomical features are believed to also affect the sound transmission loss, resulting in a high sound transmission loss despite the low specific gravity and high porosity.

\section{CONCLUSION}

The measurement of the gas permeability, sound absorption coefficient, and sound transmission loss of the Paulownia tomentosa wood using different degrees 

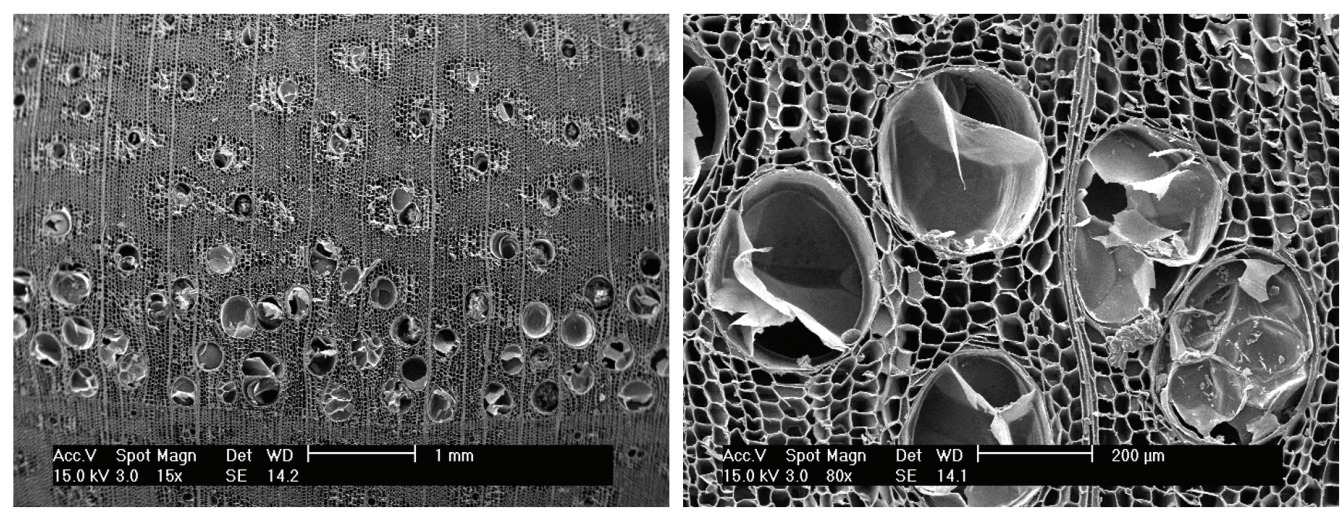

Fig. 6. Typical anatomical features of the cross-sectional surface of the Paulownia tomentosa wood.

of heat treatment resulted in the following conclusions:

1. The change in gas permeability in the Paulownia tomentosa wood that was heat-treated under the temperature conditions considered in this study was insignificant.

2. The cross-section surface of the Paulownia tomentosa wood, which is a low specific gravity material and contains big vessels, shows many tylosis and have a low sound absorption coefficient. Further, the change in its sound absorption rate due to heat treatment was insignificant.

3. The cross-sectional surface of the Paulownia tomentosa wood has a low sound absorption coefficient; therefore, it is believed that further treatment is required to improve its sound absorption coefficient for it to be used as an indoor acoustic material.

\section{ACKNOWLEDGMENT}

This research was supported by the Basic Science Research Programs through the National Research Foundation of Korea (NRF) funded by the Ministry of Science, ICT (NRF-2017R1A2B4012538) and the Ministry of Education (No. NRF-2016R1D1A1B010 08339).

\section{REFERENCES}

ASTM E2611 - 09 Standard test method for measurement of normal incidence sound transmission of acoustical materials based on the transfer matrix method.

ISO 10534-2, Acoustics-Determination of sound absorption coefficient and impedance in impedance tubes-Part 2: Transfer function method .

Jang, E.-S., Kang, C.-W., Kang, H.-Y., Jang, S.-S. 2018. Sound absorption property of traditional Korean natural wallpaper (Hanji). Journal of the Korean Wood Science and Technology 46(6): 703-712.

Kang, C.-W., Jang, E.-S., Jang, S.-S., Kang, H.-Y. 2018a. Comparison of transfer function method and reverberation room method in measuring the sound absorption coefficient of rice straw particle mat. Journal of the Korean Wood Science and Technology 46(4): 362-367.

Kang, C.-W., Jang, E.-S., Jang, S.-S., Kang, H.-Y. 2018b. Measurement of sound transmission loss in a sound barrier filled with the rice-straw particles by the transfer function and laboratory measurement methods. Journal of the Korean Wood Science and Technology 46(4): 338-345.

Kang, C.-W., Li, C., Jang, E.-S., Jang, S.-S., Kang, 
Effect of Heat Treatment on the Gas Permeability, Sound Absorption Coefficient, and Sound Transmission Loss of Paulownia tomentosa Wood

H.-Y. 2018c. Changes in sound absorption capability and air permeability of Malas (homalium foetidum) specimens after high temperature heat treatment. Journal of the Korean Wood Science and Technology 46(2): 149-154.

Kang, C.-W., Kim, G.-C., Park, H.-J., Lee, N.-H., Kang, W., Matsumura, J. 2010. Changes in permeability and sound absorption capability of yellow poplar wood by steam explosion treatment. Journal of the Faculty of Agriculture Kyushu University 55(2): 327-332.

Kang, C.-W., Lee, Y.-H., Kang, H.-Y., Kang, W., Xu, H.-R., Chung, W.-Y. 2011. Radial variation of sound absorption capability in the cross sectional surface of yellow poplar wood. Journal of the Korean Wood Science and Technology 39(4): 326-332.

Kang, C.-W., Oh, S.-W., Lee, T.-B., Kang, W., Matsumura, J. 2012. Sound absorption capability and mechanical properties of a composite rice hull and sawdust board. Journal of Wood Science 8:
273-278.

Kang, H.-Y., Lu J. 2005. Comparison of longitudinal liquid permeability of Pinus Koraiensis sapwood treated by steaming and various drying methods. Journal of the Korean Wood Science and Technology 33(6): 17-24.

Kim, D.-R., Kim, T.-M., Kim, J.-T., Park, G.-H., Ryu, L.-O. 2015. A study on sensitivity of transmission loss using scaled reverberation chamber. Transactions of the Korean Society of Noise and Vibration Engineering 4: 937-943.

Kook, J.-H., Jung, C.-W., Yun, J.-H., Kim, J.-S. 2007. Experimental study on wall sound transmission loss at construction equipment machinery room. Proceedings of the Korean Society of Noise and Vibration Engineering 2007.3: 695-699.

Lee, J.-H., Kim, B.-S., Kim, K.-J. 2011. Study of sound transmission characteristics of using a scale reverberation chamber and vibro acoustic FEM. Proceedings of the Korean Society of Noise and Vibration Engineering 10: 92-95. 


\title{
APPENDIX
}

\author{
(Korean Version)
}

\section{참오동나무의 열처리가 기체투과성, 흡음율과 음향투과손실에 미치는 영향}

초록 : 참오동나무의 섬유방향기체투과성(gas permeability), 횡단방향 흡음율(sound absorption coefficient)과 음향투과손실 (sound transmission loss)을 평가하고 열처리의 영향을 파악하고자 참오동나무 원반을 $100,160,200{ }^{\circ} \mathrm{C}$ 로 열처리하고 기체투과 성, 흡음율, 음향투과손실을 각각 측정하여 무처리 원반의 결과와 비교하였다. 그 결과, 두께 $20 \mathrm{~mm}$ 참오동나무 원반의 섬유방 향 기체투과성(specific permeability)은 무처리, $100,160,200{ }^{\circ} \mathrm{C}$ 열처리의 경우 각각 $0.254,0.279,0.314,0.452$ 로 열처리에 의해 기체투과성이 약간 증가하였다. 두께 $20 \mathrm{~mm}$ 무처리 참오동나무 원반의 50-6400 Hz 평균흡음율은 0.101이었으며 온도 $100,160,200{ }^{\circ} \mathrm{C}$ 로 열처리한 목재의 $50-6400 \mathrm{~Hz}$ 평균흡음율은 0.109, 0.096 그리고 0.106이었다. NRC (noise reduction coefficient) 는 각각 0.060, 0.067, 0.062 그리고 0.071 이었다. 두께 $20 \mathrm{~mm}$ 무처리 참오동나무 원반의 50-6400 Hz 주파수범위에 서 음향투과손실은 평균 $36.93 \mathrm{~dB}$ 이었다. 열처리에 의해 참오동나무 원반의 기체투과성과 흡음율은 열처리에 의해 그리고 열처리 온도 증가에 의해 약간 증가하였으나 증가정도는 미미하였다.

\section{1. 서 론}

최근 삶의 질 향상에 대한 관심이 고조되어 환경소음문제가 심각해지고 있으며 주거환경의 소음제어에 대한 요구가 크게 증가하고 있다. 이에 따라 흡음율이 우수한 건축자재에 대한 연구와 흡음율 측정에 관한 연구가 증가하고 있다.

흡음은 음이 가지고 있는 에너지를 소실 또는 감소시키는 과정으로, 다공성재료의 공극에서의 마찰에 의한 흡음, 강벽과 판이나 막사이에 공기층을 두고 판이나 막의 진동에 의한 흡음, 그리고 공명기를 이용한 흡음기구 등을 이용한다. (Jang et al., 2018; kang et al., 2010; kang et al., 2018a; kang et al., 2018b) 다공질형 흡음은 유리섬유나 다공성 합성수지를 이용하여 흡음효과를 낼 수 있는데 직물과 유리섬유 등이 다공질형흡음의 대표적인 예이다. 목재는 생태적특성으로 수분과 양분의 이동통 로를 제공하는 수많은 공극을 보유한 천연 다공질체인데 흡음재로의 사용은 미미하다. 목재는 수많은 공극을 가지고 있으나 공극의 방향이 수축방향이고 목재 판면을 이용할 때 주로 정목이나 판목으로 이용하므로 목재의 공극은 음입사면과 노출되지 않는다. 횡단면을 음입사면으로 할 때 목재공극이 흡음에 기여할 가능성이 있는데 이 경우에도 침엽수를 구성하는 가도관은 세포 끝부분에 천공이 없고 막공이 통로로 기능하여 흡음에 유효한 관통공극이 좁다. 활엽수의 경우 구성세포 중의 하나인 도관에 천공이 관통공극이 구성되므로 활엽수횡단면의 흡음율이 높을 수 있지만 도관직경의 크기, 도관요소 상호 간 천공판의 형태 그리고 도관의 비율 등의 수종 간 변이가 크다. 강 등은 산공활엽수인 백합나무횡단면이 도관직경이 크고 공극율이 높아서 흡음성능이 우수하다고 보고하였으며 타일로시스 등의 심재화가 진행된 부분과 변재부분 간의 흡음율 수치가 다른 방사방향변 이가 있음을 보고하였다 (Kang et al., 2011).

본 연구에서는 국내산 속성수종으로 부가가치가 높은 참오동나무재의 이용방안 확대의 주요 기초 자료를 제공하고자 참오동 나무의 기체투과성, 횡단방향 흡음율과 음향투과손실에 미치는 열처리의 영향을 파악하고자 참오동나무 원반을 100,160 , $200{ }^{\circ} \mathrm{C}$ 로 열처리하여 섬유방향 기체투과성을 측정하고 동일한 시험편으로 전달함수법으로 수직입사흡음율을 측정하고 전달행 렬법으로 음향투과손실을 각각 측정하여 무처리 원반의 기체투과성, 흡음율과 음향투과손실 결과와 비교하였다. 이를 통하여 참오동나무 섬유방향의 흡음성능과 음향투과손실을 평가하고 열처리의 영향을 파악하여 실내건축용재로의 이용가능성을 검토 하고자 하였다.

\section{2. 재료 및 방법}

\section{1. 시험편제작과 열처리}

본 연구에서는 강원대학교 학술림에서 수령 11 15년, 흥고직경 약 $30 \mathrm{~cm}$ 의 참오동나무 (Royal paulownia, Paulownia tomentosa (Thunb.) Steud.) 를 채취하여 사용하였다. 공시수종의 전건시료를 $100 \mathrm{C}^{\circ}, 160 \mathrm{C}^{\circ}, 200 \mathrm{C}^{\circ}$ 에서 2 시간 동안 열처리하 였으며, $2 \mathrm{C} / \mathrm{min}$ 조건으로 승온 하였다. 
Effect of Heat Treatment on the Gas Permeability, Sound Absorption Coefficient, and Sound Transmission Loss of Paulownia tomentosa Wood

\section{2. 기체투과성 측정}

투과성은 다공체가 유체를 통과시키는 정도를 나타내며 일반적으로 Darcy‘s law 로 나타낸다. 1 Darcy 는 $1 \mathrm{~cm}$ 거리에 $1 \mathrm{~atm}$ 의 압력 하에서 점도 $1 \mathrm{cp}(1 \mathrm{mPa} \cdot \mathrm{s})$ 의 유체를 $1 \mathrm{~cm} 3 / \mathrm{s}$ 만큼 통과시키는 것을 의미한다.

기체투과성 측정은 Capillary flow porometer (Model : CFP-1200AEL, Porous material Inc., Ithaca U.S.A)를 이용하여 Fig.1 과 같이 압력증가에 따른 유량변화를 실시간으로 측정 후 다음 식 (1)과 (2)에 의하여 specific permeability $(K)$ 로 계산하였 다(Kang and $\mathrm{Lu}, 2005)$.

$$
\begin{gathered}
k=\frac{Q / A}{\Delta P / L} \\
K=1.013 \times 10^{8} \mathrm{k \eta}
\end{gathered}
$$

$$
\begin{array}{ll}
K & =\text { specific permeability (darcy) } \\
k & =\text { permeability }\left(\mathrm{cm}^{4} / \text { dyne } \mathrm{s}\right) \\
\eta & =\text { viscosity of air }\left(=1.81 \times 10^{-4} \text { dyne } \mathrm{s} / \mathrm{cm}^{2}\right) \\
Q & =\text { gas flow rate }\left(\mathrm{cm}^{3} / \mathrm{s}\right) \\
A & =\text { cross sectional area of the specimen }\left(\mathrm{cm}^{2}\right) \\
\Delta P & =\text { pressure difference }\left(\text { dyne } / \mathrm{cm}^{2}\right) \\
L & =\text { length of the specimen }(\mathrm{cm})
\end{array}
$$

\section{3 전달함수법 흡음율 측정}

흡음율 측정은 전보와 마찬가지로 ISO 10534-2에 따라 B\&K사의 impedance tube, pulse 분석장치 그리고 스펙트럼 아날라이 저를 이용하여 전달함수법(transfer function method)으로 50-6400 Hz 주파수범위에서의 흡음율을 측정하였다(Kang et al., 2012). 흡음율측정 시, 직경 $29 \mathrm{~mm}$ 의 임피던스관을 이용하여 $50-6400 \mathrm{~Hz}$ 구간의 주파수변화에 따른 흡음율 변이를 측정하였다.

측정 시 외부조건은 온도, 상대습도, 기압이 각각, $18.7 \mathrm{C}^{\circ}, 37 \%, 1027.50 \mathrm{hPa}$ 이었고 음속, 공기밀도 그리고 음향임피던스는 각각 $342.48 \mathrm{~m} / \mathrm{s}, 1.224 \mathrm{~kg} / \mathrm{m}^{3}, 419.3 \mathrm{~Pa} /(\mathrm{m} / \mathrm{s})$ 이었다.

\section{4 전달행렬법 음향투과손실측정}

음향투과계수 측정은 ASTM E2611-09 에 따라 B\&K사의 impedance tube와 pulse분석장치 그리고 스펙트럼 아날라이저를 이용하여 전달행렬법 (transfer matrix method) 으로 측정하였다. 측정 시, 직경 $29 \mathrm{~mm}$ 의 임피던스튜브를 이용하여 50-6400 $\mathrm{Hz}$ 범위의 주파수대역에서 투과손실을 측정하였으며 측정 시 외부조건은 온도, 기압이 각각, $20{ }^{\circ} \mathrm{C}, 1031 \mathrm{hPa}$ 이었다.

\section{5 주사전자현미경관찰}

흡음율, 기체투과성 그리고 음향투과계수을 측정한 시험편에서 목재 횡단면의 공극 구조를 관찰하기 위하여 목재시편을 약 $10 \mathrm{~mm}(\mathrm{~T}) \times 10 \mathrm{~mm}(\mathrm{R}) \times 10 \mathrm{~mm}(\mathrm{~L})$ 로 절취 후 감압조건에서 48시간 수침시켜 연화처리한 후 Microtome (Model: HM400S, MicromGmbH, Germany)을 이용하여 단면을 매끄럽게 절삭하고 Philips제 주사전자현미경(Scanning electron micrography, XL30ESEM, Philips, Netherlands)을 이용하여 관찰하였다.

\section{3. 결과 및 고찰}

\section{1. 기체투과성}

Fig. 3에는 무처리와 열처리참오동나무의 기체투과성 변화를 나타내고 있다. 두께 $20 \mathrm{~mm}$ 로 온도 $100,160,200{ }^{\circ} \mathrm{C}$ 로 열처리온 도를 변화시켰을 때의 투과성(specific permeability)은 0.254, 0.279, 0.314, 0.452 darcy로 나타나 기체투과성은 열처리에 의해 약간 증가하는 경향을 나타내었다. 참오동나무는 비중이 작아서 공극율이 크고 대경도관을 함유하고 있어서 기체투과성이 높고 흡음율이 특히 고주파수영역에서 흡음율이 높을 가능성이 있으나 전반적으로 낮은 수치를 나타내었다. 이는 기체투과성 증가에 기여하는 대형도관이 제 기능을 하지 못한 것을 의미하는데 참오동나무 도관의 횡단면은 Fig. 6과 같이 타일로시스가 다수 관찰되어 유체통과에 기여하는 관통공극이 적어 기체투과성이 낮은 원인을 알 수 있었다. 열처리에 의해서 무처리에 비해 기체투과성이 약간 증가하였다. Kang et al. (2018c)은 말라스를 $200{ }^{\circ} \mathrm{C}$ 에서 3시간 열처리하고 기체투과성과 흡음율변화를 


\section{Chun-Won KANG $\cdot$ Eun-Suk JANG $\cdot$ Sang-Sik JANG $\cdot$ Jae-Ik Cho $\cdot$ Nam-Hun KIM}

관찰하였는데 투과성은 8 배 증가하였고 흡음율은 $40 \%$ 증가하는 결과를 보고하였다. 본 연구의 결과는 선행 연구의 결과와 비교하여 열처리의 효과가 적은 편인데 이는 수종 간 공극의 구조와 크기 차이, 관통공극 함량, 수지함량의 차이, 처리온도와 처리시간 등의 처리조건의 차이 등에서 그 원인을 찾을 수 있을 것이며 이에 대한 추가 연구가 수행되어야 할 것으로 사료된다.

\section{2. 전달함수법 흡음율}

Fig. 4에 전달함수법으로 구한 열처리참오동나무의 $50-6400 \mathrm{~Hz}$ 주파수범위에서의 흡음율을 나타내고 있다. 두께 $20 \mathrm{~mm}$ 무처리 참오동나무 원반의 평균흡음율은 0.101 이며 온도 $100,160,200{ }^{\circ} \mathrm{C}$ 로 열처리하였을 때 평균흡음율은 $0.109,0.096$ 그리고 0.106 이었다. NRC (noise reduction coefficient)는 각각 $0.060,0.067,0.062$ 그리고 0.071 이었다.

목재가 판재상태로 사용될 때 방사단면이나 접선단면에 음이 입사하면 목재공극이 흡음에 기여하기 어렵다. 반면 목재의 횡단면에 음이 입사하면 목재공극이 흡음에 기여하기 용이하므로 관통공극을 많이 함유한 목재의 횡단면이 흡음율이 높을 가능성이 있다. 국산 속성수종 중의 하나인 참오동나무는 비중이 작으면서 공극율이 크고 대경도관을 가지고 있어서 횡단방향의 흡음율이 높을 가능성이 있었으나 측정주파수 전 대역에서 전반적으로 $10 \%$ 전후의 흡음율을 나타내어 낮은 수치를 나타내었다. 일반적으로 다공체는 고주파수영역에서의 흡음율이 증가하는데 참오동나무는 공극율은 높지만 타일로시스가 발달하여 다수의 공극이 폐쇄되어 고주파수영역에서의 흡음율도 높지 않은 것으로 생각되었다. 또한 열처리를 한 경우에도 흡음율증가가 미미했 는데 이는 다공질형 흡음에 기여하는 관통공극의 비율이 크지 않고 열처리에 의해서도 구조적변화가 없었음을 나타낸다. 한편, Kang et al. (2018c)은 말라스를 $190{ }^{\circ} \mathrm{C}$ 로 3시간 열처리하고 흡음율변화를 관찰하여 흡음율이 2배 가까이 증가하는 결과를 보고하였다. 본 연구의 결과는 선행 연구의 결과와 비교하여 열처리에 의한 변화가 적은 편인데 이는 수종 간 공극 차이, 수지함량의 차이, 처리온도와 처리시간 등의 처리조건의 차이 등에서 그 원인을 찾을 수 있을 것이며 이에 대한 추가 연구가 수행되어야 할 것으로 사료된다. 한편, 다공질체의 흡음특성은 저주파수보다 고주파수영역에서 흡음율이 증가하는 것으로 알려져 있는데 참오동나무는 저주파수영역과 고주파수영역 공히 낮은 흡음율을 나타내었다. 이는 참오동나무의 관공배열이 산공재로 대경도관이 넓은 지역에 산재하여 다공체의 특성은 갖고 있으나 대경도관에 타일로시스가 다수 발생하여 관통공극의 비율이 감소하여 고주파수영역에서의 흡음율도 크지 않은 것으로 사료된다.

\section{3. 전달행렬법 음향투과손실}

Fig. 5는 50-6400 Hz 주파수범위에서의 $20 \mathrm{~mm}$ 두께 참오동나무 원반의 음향투과손실을 나타내고 있다.

음향투과손실은 재료가 음을 차단하는 효과를 나타내는 값으로 투과손실이 크면 차음효과가 커지며 주파수에 따라 다른 수치를 나타낸다(Kim et al., 2015; Kook et al., 2007; Lee et al., 2011). 그래프 X축에는 주파수, Y축에는 음향투과손실을 나타내고 있는데 투과손실은 [dB]로 표시되며, 일반적으로 주파수가 높을수록, 또 재료의 면적밀도가 클수록 즉 밀도가 높거나 두께가 두꺼워질수록 큰 값을 나타낸다. 두께 $20 \mathrm{~mm}$ 무처리 참오동나무 원반의 음향투과손실은 50-6400 측정주파수범위에서 $30-40 \mathrm{~dB}$ 정도의 수치를 나타내고 평균 $36.93 \mathrm{~dB}$ 로 나타났다. 참오동나무의 경우 비중이 낮고 공극이 많은 반면에 투과손실은 비교적 높은 수치를 나타내었다.

\section{4. 구조적 특성}

Fig. 6은 참오동나무 횡단면의 구조적특성을 나타내고 있다. 그림에서 알 수 있듯이 참오동나무는 산공재로 대형도관이 산재하여 흡음에 기여하는 단면의 비율이 넓은 반면에 흡음에 기여하는 대형도관에 타일로시스가 다수 발견되어 전반적으로 흡음율이 낮은 원인을 알 수 있었다. 이러한 구조적 특징은 음향투과손실에도 영향을 미쳐 저비중 다공성 목재인 참오동나무가 비교적 높은 음향투과손실을 나타내게 하는 원인이라고 생각되었다.

\section{4. 결 론}

참오동나무의 열처리 정도를 달리하여 기체투과성, 흡음율과 음향투과손실을 측정한 결과 다음과 같은 결론은 얻었다.

1. 본 연구의 온도조건으로 열처리한 오동나무 원반의 기체투과성의 변화는 미미하였다.

2 저비중재이면서 대경도관을 보유한 참오동나무 횡단면은 타일로시스가 다수 존재하여 흡음율이 낮았으며 열처리에 의해 흡음률변화도 미미하였다.

3. 참오동나무 횡단면은 흡음율이 낮아서 실내음향재로 사용하기 위해서는 흡음율을 제고하는 처리가 필요하다고 사료되었다. 